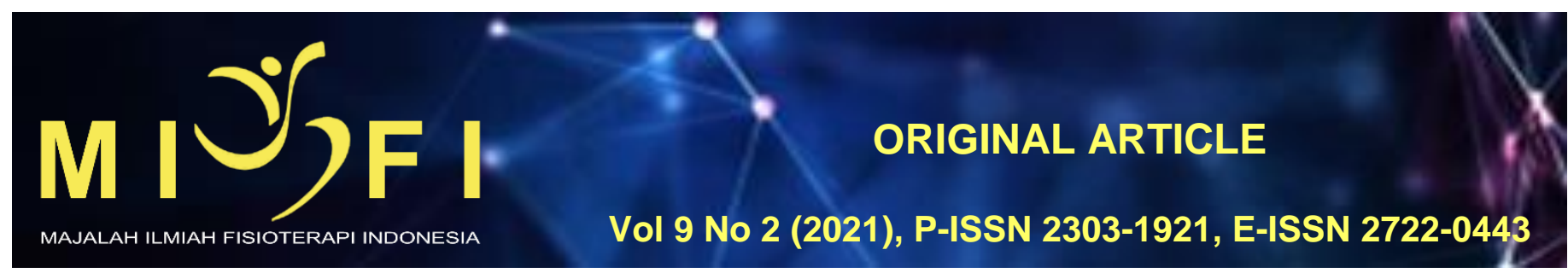

\title{
UJI VALIDITAS DAN RELIABILITAS KUESIONER QUICK DISABILITIES OF THE ARM, SHOULDER AND HAND VERSI INDONESIA PADA PASIEN CARPAL TUNNEL SYNDROME
}

\author{
Tirza Nanda Kristanti ${ }^{1}$, Made Hendra Satria Nugraha ${ }^{2}$, I Made Niko Winaya ${ }^{3}$, \\ Anak Ayu Nyoman Trisna Narta Dewi ${ }^{4}$ \\ ${ }_{1}^{1}$ Program Studi Sarjana Fisioterapi dan Profesi Fisioterapi, Fakultas Kedokteran Universitas Udayana, Denpasar, Bali \\ 2,3,4Departemen Fisioterapi, Fakultas Kedokteran Universitas Udayana, Denpasar, Bali \\ nandatirza@gmail.com
}

\begin{abstract}
ABSTRAK
Carpal tunnel syndrome (CTS) merupakan suatu sindrom yang terjadi akibat adanya penekanan pada nervus medianus didalam terowongan karpal yang terletak di regio wrist. Salah satu alat ukur untuk kasus CTS adalah kuesioner Quick DASH dimana kuesioner ini digunakan untuk mengukur gejala dan fungsi fisik dengan gangguan pada ekstremitas atas. Alat ukur yang baik yaitu alat ukur yang memiliki validitas dan reliabilitas yang baik, maka perlu dilakukan uji valilditas dan reliabilitas pada kuesioner untuk membuktikannya sehingga kuesioner dapat digunakan dalam pengukuran pada kasus CTS dan dapat membantu pasien dalam menggambarkan kondisi atau keluhan yang dialami pasien tersebut. Validitas adalah ketepatan suatu alat ukur dalam memberikan hasil, sedangkan reliabilitas adalah sejauh mana alat ukur dapat dipercaya. Penelitian ini merupakan penelitian observasioal analitik dengan menggunakan teori rules of thumb dengan teknik pengambilan sampel purposive sampling dengan jumlah sampel penelitian sebanyak 55 subjek. Analisis data uji validitas dengan menggunakan pearson product moment untuk menilai construct validity didapatkan nilai $p<0,05$ dengan rhitung $>$ rtabel pada seluruh item pertanyaan kuesioner Quick DASH versi Indonesia, sehingga hasil construct validity untuk kuesioner Quick DASH versi Indonesia menunjukkan nilai validitas yang tinggi $(0,60<r \leq 0,80)$ hingga sangat tinggi $(0,80<r \leq 1.00)$. Uji reliabilitas dengan menggunakan cronbach alpha untuk mengukur internal consistency didapatkan hasil 0,946 dan menunjukkan nilai reliabilitas yang sangat tinggi $(0,800<r \leq 1.000)$ serta menggunakan interclass correlation coeficient (spearman's correlation coeficient) untuk mengukur test-retest reliability didapatkan nilai reliabilitas 0,676 , dimana hasil menunjukkan nilai reliabilitas yang tinggi $(0,600<r \leq 0,799)$. Berdasarkan hasil penelitian, maka dapat disimpulkan bahwa kuesioner Quick DASH memilliki nilai validiitas dan reliabilitas yang baik.
\end{abstract}

Kata Kunci: uji validitas dan reliabilitas, kuesioner Quick Disabilities of the Arm, Shoulder and Hand, Carpal Tunnel Syndrome

\section{VALIDITY AND RELIABILITY TEST OF QUICK DISABILITIES OF THE ARM, SHOULDER AND HAND VERSION OF INDONESIA IN PATIENTS WITH CARPAL TUNNEL SYNDROME}

\section{ABSTRACT}

CTS is a syndrome that occurs due to pressure on the median nerve in the carpal tunnel located in the wrist region. One of the measurement tools for CTS cases is the Quick DASH questionnaire where this questionnaire is used to measure disorders of the upper limb. A good measuring instrument that is a measuring tool that has good validity and reliability, it is necessary to test the validity and reliability of the questionnaire to prove it so that the questionnaire can be used in measurements in CTS cases and can help describe the conditions by these patients. Validity is accuracy of a measuring instrument in providing results, reliability is the extent to which the measuring tool can be trusted. This research was an analytic observational study using rules of thumb theory with a purposive sampling technique with 55 sample. Analysis of the validity test data using Pearson product moment to assess construct validity obtained a value of $p<0.05$ with rcount $>$ rtable on all items of the Quick DASH Indonesian version, so the construct validity results for the Quick DASH Indonesian version showed high validity values to very high. The reliability test using Cronbach alpha to measure internal consistency obtained 0.946 and showed a very high reliability value and using the interclass correlation coefficient to measure the test-retest reliability obtained a reliability value of 0.676 , where the results showed high value. Based on the results, it can be concluded that the Quick DASH questionnaire has good validity and reliability values. Keywords: validity and reliability test, Quick Disabilities of the Arm questionnaire, Shoulder and Hand, Carpal Tunnel Syndrome

\section{PENDAHULUAN}

Carpal Tunnel Syndrome (CTS) merupakan suatu sindrom yang terjadi akibat adanya penekanan pada nervus medianus didalam terowongan karpal yang terletak di regio wrist. ${ }^{1}$ CTS adalah salah satu jenis keluhan yang sering terjadi dalam golongan Cummulative Trauma Disorders (CTD) dengan prevalensi sebesar $40 \%$, sedangkan CTD termasuk dalam penyebab keluhan pada ekstremitas atas. CTS $10 \%$ lebih sering terjadi pada orang dewasa dengan kasus pada wanita tiga kali lebih banyak dibandingkan pada pria. ${ }^{2}$ Jumlah kasus pada CTS ada 345 kasus baru per 100.000 orang dalam rentang waktu 1 tahun. ${ }^{3}$ Menurut Survei Populasi Besar Belanda menunjukkan prevalensi CTS 
sebesar $0,6 \%$ dan $8 \%$ pada wanita. ${ }^{4}$ Menurut National Health Interview Survey, CTS lebih sering terjadi pada wanita dibandingkan pria dengan rantang usia 25-64 tahun. Penekanan yang terjadi pada nervus medianus dapat terjadi karena adanya peradangan pada jaringan disekitarnya yang menyebabkan jaringan tersebut mengalami pembengkakan dan terjadi penyempitan pada terowongan karpal. ${ }^{5}$ Apabila penekanan pada nervus medianus dibiarkan terus-menerus akan menimbulkan berbagai macam gejala seperti nyeri, kesemutan, keterbatasan dalam melakukan aktivitas sehari-hari dan dalam melakukan pekerjaan, serta gangguan tidur dan juga dapat menyebabkan terjadinya kelemahan dan kerusakan pada otot-otot tenar. ${ }^{1}$ CTS dapat terjadi karena dipengaruhi oleh beberapa faktor seperti trauma pada pergelangan tangan, pekerjaan dengan gerakan fleksi dan ekstensi yang berulang-ulang, tendosinovitis dan penyebab lainnya yaitu diabetes millitus, kehamilan dan osteoartritis. ${ }^{6}$ Gejala awal CTS umumnya hanya gangguan sensorik dan dapat menjadi gengguan motorik jika dalam keadaan yang berat. Gejala awal yang biasa terjadi yaitu hipotesia dan parestesia pada malam hari serta rasa kebas pada jari 1-3 dan sisi lateral jari $4 .^{7}$

CTS pada umumnya terjadi secara kronis dimana terjadi penebalan fleksor retinakulum yang menyebabkan nervus medianus tertekan, tekanan yang terjadi berulang-ulang dan dalam durasi yang lama akan mengakibatkan tekanan intravaskuler meningkat yang mengakibatkan aliran darah terganggu dan berdampak merusak endotel. Endotel yanng mengalami kerusakan mengakibatkan kebocoran protein sehingga dapat terjadi edema epineural. Apabila keadaan tersebut berkelanjutan akan terjadi fibrosis epineural yang akan merusak serabut saraf dan fungsi saraf akan terganggu. ${ }^{6}$ CTS juga dapat dibilang sebagai salah satu penyakit inflamasi yaitu reaksi normal apabila jaringan mengalami kerusakan akibat cedera yang berulang, trauma atau kondisi lainnya. Inflamasi yang terjadi secara terusmenerus pada terowongan karpal akan menyebabkan terjadinya jebakan pada nervus medianus. ${ }^{8}$ Apabila terjadi gejala perlu dilakukan pemeriksaan fisik untuk menegakkan diagnosis, pemeriksaan fisik yang sering dilakukan untuk kasus CTS yaitu phalen's test, pressure test, tinnel's sign dan filck's sign. ${ }^{5}$

Pengukuran CTS juga dapat dilakukan menggunakan alat ukur kuesioner. Salah satu alat ukur untuk kasus CTS adalah kuesioner Quick Disabilities of the Arm, Shoulder and Hand (Quick DASH) dimana kuesioner ini adalah bentuk singkat dari kuesioner DASH yang digunakan untuk mengukur gejala dan fungsi fisik dengan gangguan pada ekstremitas atas. Kuesioner Quick DASH terdiri dari 11 pertanyaan yang menggambarkan mengenai keparahan nyeri, rasa kesemutan, kesulitan yang terkait pekerjaan atau aktivitas sehari-hari akibat adanya gangguan pada ekstremitas atas, keterbatasan dalam melakukan aktivitas sosial dan gangguan tidur. ${ }^{9}$ Kuesioner Quick DASH memiliki penilaian skor dengan rentang nilai 0 berarti tidak adanya gangguan fungsional hingga 100 berarti adanya gangguan fungsional yang berat. ${ }^{10}$

Dilakukannya penelitian ini bermaksud untuk mendapatkan alat ukur yang baik yaitu alat ukur yang memiliki validitas dan reliabilitas yang baik, maka perlu dilakukan uji valilditas dan reliabilitas pada kuesioner untuk membuktikannya sehingga kuesioner dapat digunakan dalam pengukuran pada kasus CTS dan dapat membantu pasien dalam menggambarkan kondisi atau keluhan yang dialami pasien tersebut. ${ }^{11}$ Menguji validitas dan reliabilitas perlu dilakukan adaptasi lintas budaya. Adaptasi lintas budaya merupakan proses memodifikasi instrumen ke dalam versi yang sesuai pada nilai sosial dan budaya, termasuk bahasa tanpa mengubah makna dari versi asli instrumen tersebut. $^{12}$ Validitas adalah ketepatan suatu alat ukur dalam memberikan hasil yang sesuai dengan maksud dilakukannya pengukuran itu dalam artian hasil dari alat ukur tersebut dapat memberikan hasil yang tepat sesuai dengan keadaan sesungguhnya. Sedangkan reliabilitas adalah tingkat kepercayaan alat ukur dimana jika dalam beberapa kali pengukuran yang dilakukan pada subjek yang sama dengan aspek yang diukur sama akan menunjukkan hasil pengukuran yang relatif sama. ${ }^{13}$ Berdasarkan latar belakang diatas, maka perlu dilakukan penelitian mengenai "Uji Validitas dan Reliabilitas Kuesioner Quick Disabilities of the Arm, Shoulder and Hand Versi Indonesia pada Pasien Carpal Tunnel Syndrome".

\section{METODE}

Penelitian ini merupakan penelitian observasioal analitik dengan menggunakan teori rules of thumb dengan teknik pengambilan sampel purposive sampling dengan jumlah sampel penelitian sebanyak 55 subjek. Penelitian ini dilakukan di klinik fisioterapi di kota Denpasar pada bulan Oktober 2019-Februari 2020. Sampel penelitian yang diambil adalah individu yang memenuhi kriteria inklusi yaitu pasien dengan diagnosis carpal tunnel syndrome, dapat berkomunikasi dalam bahasa Indonesia, bersedia mengisi informed consent dan bersedia mengisi kuesioner sebanyak 2 kali serta kriteria eksklusi yaitu tidak menjawab lebih dari tiga pertanyaan pada masing-masing kuesioner, pasien dengan gangguan pada regio shoulder, pernah mengalami fraktur pada regio wrist, pasien dengan trigger finger dan pasien dengan de quervain syndrome. Sedangkan dengan kriteria drop out yaitu tidak mengisi kuesioner sebanyak 2 kali.

Data yang diperoleh dari penelitian ini merupakan data hasil pengisian kuesioner Quick DASH yang digunakan untuk mengukur tingkat disabilitas pada pasien dan dilakukan sebanyak 2 kali yaitu sebelum dan sesudah diberikan intervensi oleh fisioterapis. Analisis data pada penelitian ini menggunakan software SPSS yang dibagi menjadi tiga yaitu analisis statistik deskriptif untuk menggambarkan profil subjek penelitian, uji validitas dengan menggunakan pearson product moment untuk menilai construct validity dan uji reliabilitas dengan menggunakan cronbach alpha untuk mengukur internal consistency dan menggunakan interclass correlation coeficient (spearman's correlation coeficient) untuk mengukur test-retest reliability.

\section{HASIL}

Total sampel dalam penelitian ini berjumlah 55 orang dengan diagnosa carpal tunnel syndrome. Berikut adalah gambaran umum subjek penelitian berdasarkan usia dan jenis kelamin dari 55 orang dengan diagnosa carpal tunnel syndrome di klinik fisioterapi di kota Denpasar. 
Tabel 1. Distribusi Frekuensi Subjek Berdasarkan Usia

\begin{tabular}{ccc}
\hline Usia & Frekuensi & Persentase (\%) \\
\hline $21-30$ & 15 & 27,27 \\
$31-40$ & 17 & 30,91 \\
$41-50$ & 16 & 29,09 \\
$51-57$ & 7 & 12,73 \\
\hline Total & 55 & 100 \\
\hline
\end{tabular}

Berdasarkan Tabel 1 dapat dilihat rentang usia dari 55 subjek penelitian ini adalah 21-57 tahun dengan jumlah terbanyak di rentang usia 21-40 tahun yang berjumlah 17 orang $(30,91 \%)$.

Tabel 2. Distribusi Frekuensi Subjek Berdasarkan Jenis Kelamin

\begin{tabular}{ccc}
\hline Jenis Kelamin & Frekuensi & Persentase (\%) \\
\hline Perempuan & 30 & 54,55 \\
Laki-laki & 25 & 45,45 \\
\hline Total & 55 & 100
\end{tabular}

Berdasarkan Tabel 2 dapat dilihat bahwa subjek penelitian perempuan lebih banyak dari pada subjek penelitian laki-laki dengan jumlah subjek penelitian perempuan 30 orang (54,55\%) dan laki-laki 25 orang (45,45\%).

Hasil pengukuran tingkat disabilitas dengan menggunakan kuesioner Quick DASH telah dilakukan pada semua subjek penelitian. Prosedur pengukuran dilakukan sebanyak dua kali yaitu sebelum diberikan intervensi dan 3-4 hari setelah diberikan intervensi. Adapun hasil pengukuran yang didapat yaitu pada hasil pengukuran tingkat disabilitas yang kedua lebih kecil dibandingkan dengan hasil pengukuran tingkat disabilitas yang pertama.

Uji validitas dilakukan dengan menggunakan pearson product moment untuk menilai construct validity.

Tabel 3. Hasil Uji Validitas Kuesioner Quick DASH Versi Indonesia

\begin{tabular}{llccc}
\hline No & Pertanyaan & $r$ hasil & $r$ tabel & Nilai $p$ \\
\hline 1 & Membuka botol & 0,889 & 0,000 \\
2 & Pekerjaan rumah tangga & 0,821 & 0,000 \\
3 & Membawa tas belanja & 0,754 & 0,000 \\
4 & Menggosok punggung & 0,746 & 0,000 \\
5 & Menggunakan pisau & 0,809 & 0,000 \\
6 & Kegiatan dengan kekuatan lengan & 0,801 & 0,2656 & 0,000 \\
7 & Kegiatan sosial & 0,791 & 0,000 \\
8 & Pekerjaan/kegiatan sehari-hari & 0,830 & 0,000 \\
9 & Rasa nyeri & 0,856 & 0,000 \\
10 & Rasa kesemutan & 0,734 & 0,000 \\
11 & Kesulitan tidur & 0,873 & 0,000 \\
\hline
\end{tabular}

Berdasarkan penilaian construct validity diatas, nilai $r$ tabel yang ditetapkan untuk jumlah sampel 55 adalah 0,2656 . Pada uji construct validity didapatkan nilai $p<0,05$ dengan rhitung $>$ rtabel pada seluruh item pertanyaan kuesioner Quick DASH, sehingga hasil construct validity untuk kuesioner Quick DASH versi Indonesia menunjukkan nilai validitas yang tinggi $(0,60<r \leq 0,80)$ hingga sangat tinggi $(0,80<r \leq 1.00)$.

Uji reliabilitas dilakukan dengan menggunakan cronbach's alpha untuk mengukur internal consistency dan menggunakan interclass correlation coefficient untuk mengukur test-retest reliability.

Tabel 4. Hasil Uji Reliabilitas Kuesioner Quick DASH Versi Indonesia Menggunakan Cronbach's Alpha

\begin{tabular}{cc}
\hline $\mathrm{N}$ item & Koefisien reliabilitas \\
\hline 11 & 0,946 \\
\hline Item & Nilai cronbach's alpha \\
\hline Pertanyaan 1 & 0,937 \\
Pertanyaan 2 & 0,941 \\
Pertanyaan 3 & 0,944 \\
Pertanyaan 4 & 0,945 \\
Pertanyaan 5 & 0,941 \\
Pertanyaan 6 & 0,941 \\
Pertanyaan 7 & 0,942 \\
Pertanyaan 8 & 0,940 \\
Pertanyaan 9 & 0,939 \\
Pertanyaan 10 & 0,944 \\
Pertanyaan 11 & 0,939 \\
\hline
\end{tabular}

Berdasarkan tabel diatas dapat dilihat hasil uji reliabilitas dari kuesioner Quick DASH versi Indonesia adalah 0,946 dan semua item pertanyaan kuesioner Quick DASH memiliki niali cronbach's alpha diatas 0,90. Hasil uji reliabilitas pada kuesioner Quick DASH versi Indonesia menunjukkan nilai reliabilitas yang sangat tinggi $(0,800<r \leq 1.000)$. 
Tabel 5. Hasil Uji Reliabilitas Kuesioner Quick DASH Versi Indonesia Menggunakan Interclass Correlation Coefficient

\begin{tabular}{cccccccc}
\hline & \multirow{2}{*}{ Intraclass Correlation } & \multicolumn{2}{c}{$95 \%$ Confidence Interval } & \multicolumn{3}{c}{ F Test with True Value 0 } \\
\cline { 3 - 7 } Single Measures & 0.676 & Lower Bound & Upper Bound & Value & df1 & df2 & Sig \\
Average Measures & 0.807 & 0.502 & 0.797 & 5.176 & 54 & 54 & 0.000 \\
nnyyyyyy & 0.669 & 0.889 & 5.176 & 54 & 54 & 0.000 \\
\hline
\end{tabular}

Berdasarkan tabel diatas menunjukkan nilai hasil uji reliabilitas dengan menggunakan interclass correlation coefficient untuk mengukur test-retest reliability adalah 0,676 , dimana hasil uji menunjukkan nilai reliabilitas yang tinggi $(0,600<r \leq 0,799)$.

\section{DISKUSI \\ Gambaran Umum Subjek Penelitian}

Penelitian ini dilaksanakan pada bulan Oktober 2019-Februari 2020 di klinik fisioterapi di kota Denpasar dengan subjek penelitian pasien carpal tunnel syndrome dan jumlah sampel sebanyak 55 orang. Menurut NHIS (National Health Interview Survey) CTS lebih sering terjadi pada perempuan dibandingkan pada laki-laki dengan rentang usia 25-64 tahun. ${ }^{5}$ Berdasarkan distribusi frekuensi usia diperoleh rentang usia subjek 21-57 tahun dan berdasarkan jenis kelamin didapat subjek penelitian perempuan lebih banyak daripada laki-laki dengan jumlah subjek perempuan sebanyak 30 orang $(54,55 \%)$ dan laki-laki sebanyak 25 orang $(45,45 \%)$.

\section{Hasil Pengukuran Tingkat Disabilitas}

Hasil pengukuran tingkat disabilitas menunjukkan hasil pengukuran kedua lebih kecil daripada pengukuran pertama. Hasil pengukuran tingkat disabiliitas pertama memiliki skor terkecil 14 dan skor terbesar 38 sedangkan pada pengukuran tingkat disabilitas kedua memiliki skor terkecil 12 dan skor tebesar 29. Hasil dari perhitungan nilai skor Quick DASH sendiri yaitu pada pengukuran tingkat disabilitas pertama didapat skor terkecil 6,82 dan skor terbesar 61,36 sedangkan pada pengukuran tingkat disabilitas kedua didapat skor terkecil 2,27 dan skor terbesar 40,91. Rentang nilai skor Quick DASH yaitu 0 berarti tidak ada keterbatasan fungsi dan nilai skor 100 berarti adanya keterbatasan fungsi yang berat. ${ }^{10}$

\section{Hasil Uji Validitas Kuesioner}

Uji validitas dilakukan dengan menggunakan pearson product moment untuk menilai construct valildity. Construt validity adalah salah satu jenis validitas yang membahas mengenai sejauh mana butir-butir suatu instrumen dapat mengukur sesuai dengan definisi konseptual atau konsep khusus yang sudah ditetapkan. ${ }^{12}$ Ditetapkan nilai $r$ tabel untuk sampel 55 adalah 0,2656. Berdasarkan tabel 3 juga dapat dilihat bahwa item pertanyaan 1 memiliki nilai $r$ hasil 0,889 , item pertanyaan 2 memiliki $r$ hasil 0,821 , item pertanyaan 3 memiliki r hasil 0,754 , item pertanyaan 4 memiliki $r$ hasil 0,746 , item pertanyaan 5 memiliki $r$ hasil 0,809 , item pertanyaan 6 memiliki $r$ hasil 0,801 , item pertanyaan 7 memiliki $r$ hasil 0,791, item pertanyaan 8 memiliki r hasil 0,830, item pertanyaan 9 memiliki $r$ hasil 0,856, item pertanyaan 10 memiliki $r$ hasil 0,734 dan item pertanyaan 11 memiliki $r$ hasil 0,873 . Pada uji construct validity didapatkan nilai $p<0,05$ dengan $r_{\text {hitung }}>$ rabel pada seluruh item pertanyaan kuesioner Quick DASH versi Indonesia, sehingga hasil construct validity untuk kuesioner Quick DASH versi Indonesia menunjukkan nilai validitas yang tinggi $(0,60<r \leq 0,80)$ hingga sangat tinggi $(0,80<r \leq 1.00)$.

\section{Hasil Uji Reliabilitas Kuesioner}

Uji Reliabilitas dilakukan dengan menggunakan cronbach's alpha untuk mengukur internal consistency dan menggunakan interclass correlation coefficient untuk mengukur test-retest reliability. Berdasarkan tabel 4 hasil uji reliabilitas dengan menggunakan cronbach's alpha adalah 0,946 dengan item pertanyaan 1 memiliki nilai cronbach's alpha 0,937, item pertanyaan 2 memiliki nilai cronbach's alpha 0,941, item pertanyaan 3 memiliki nilai cronbach's alpha 0,944 , item pertanyaan 4 memiliki nilai cronbach's alpha 0,945 , item pertanyaa 5 memiliki nilai cronbach's alpha 0,941, item pertanyaan 6 memiliki nilai cronbach's alpha 0,941, item pertanyaan 7 memiliki nilai cronbach's alpha 0,942, item pertanyaan 8 memiliki nilai cronbach's alpha 0,940, item pertanyaan 9 memiliki nilai cronbach's alpha 0,939, item pertanyaan 10 memiliki nilai cronbach's alpha 0,944 dan item pertanyaan 11 memiliki nilai cronbach's alpha 0,939. Hasil uji internal consisitency pada kuesioner Quick DASH versi Indonesia menunjukkan nilai reliabilitas yang sangat tinggi $(0,800<r \leq 1.000)$.

Berdasarkan tabel 5 hasil uji reliabilitas dengan menggunakan interclass correlation coefficient menunjukkan nilai reliabilitas 0,676 , dimana hasil test-retest reliability menunjukkan nilai reliabilitas yang tinggi $(0,600<r \leq 0,799)$.

Alat ukur dapat dikatakan memiliki validitas yang baik apabila alat ukur tersebut dapat berfungsi dengan baik dan tepat atau memberikan hasil yang sesuai dengan maksud dilakukannya pengukuran itu dalam artian hasil dari alat ukur tersebut dapat memberikan hasil yang tepat sesuai dengan keadaan sesungguhnya. Suatu alat ukur dapat dikatakan valid atau memiliki nilai validitas yang baik apabila nilai koefisien korelasi dari setiap item pertanyaan memiliki nilai diatas 0,60 serta hasil yang dibandingkan dengan nilai tabel pada tingkat kepercayaan $95 \%$ maka suatu alat ukur dikatakan valid apabila nilai rhitung $_{\text {r }}$ tabel. ${ }^{13}$

Alat ukur yang baik tidak hanya memiliki validitas yang baik namun juga harus memiliki reliabilitias yang baik untuk membuktikan bahwa alat ukur tersebut dapat dipercaya. Alat ukur dapat dikatakan memiliki reliabilitas yang baik apabila dalam beberapa kali pengukuran yang dilakukan pada subjek yang sama dengan aspek yang diukur sama dan menunjukkan hasil pengukuran pada subjek yang relatif sama. Pengujian alat ukur dapat dikatakan reliabel atau memiliki nilai reliabilitas yang baik apabila nilai koefisien korelasi yang didapat diatas $0,60 .{ }^{13}$ 
Berdasarkan hasil penelitian, maka dapat disimpulkan bahwa kuesioner Quick DASH memilliki nilai validiitas dan reliabilitas yang baik.

\section{DAFTAR PUSTAKA}

1. Utomo B, Wahyono Y. Perbedaan Pengaruh Antara Mobilisasi Saraf dan Myofacial Release Terhadap Penurunan Nyeri Pada Pasien Carpal Tunnel Syndrome. Jurnal Terpadu IImu Kesehatan. 2017;6(2):201-207.

2. Daryono, Wibawa A. dan Tianing NW. Intervensi Ultrasound Dan Free Carpal Tunnel Exercise Lebih Efektif Dibanding Ultrasound Dan Gliding Exercise Terhadap Penurunan Nyeri Pada Kasus Carpal Tunnel Syndrome. Majalah IImiah Fisioterapi Indonesia. 2014;2(1).

3. Bakhsh H, Ibrahim I, Khan W, Smitham P, Goddard N. Assessment of Validity, Reliability, Responsiveness and Bias of Three Commonly Used Patient-Reported Outcome Measures in Carpal Tunnel Syndrome. Ortopedia Traumatologia Rehabilitacja. 2012;14(4):4-4.

4. Palmer K. Carpal tunnel syndrome: The role of occupational factors. Best Practice \& Research Clinical Rheumatology. 2011;25(1):15-29.

5. Lazuardi A. Determinan Gejala Carpal Tunnel Syndrome (CTS) Pada Pekerja Pemecah Batu (Studi Pada Pekerja Pemecah Batu di Kecamatan Sumbersari dan Sukowono Kabupaten Jember). Jember: Skripsi Universitas Jember. 2016.

6. Putri I. Hubungan Gerakan Repitisi dan Indeks Massa Tubuh (IMT) dengan Kejadian Carpal Tunnel Syndrome (CTS) pada Pengrajin Batik Tulis di Kemiling Bandar Lampung. Bandar Lampung: Skripsi Universitas Lampung. 2015.

7. Arimbawa IK, Putra IGNP, Mahayani NKD, Purwata TE. Profil Pasien Carpal Tunnel Syndrome Di Poliklinik Saraf Rsup Sanglah Denpasar. Denpasar: SMF Neurologi Fakultas Kedokteran Universitas Udayana/RSUP Sanglah Denpasar. 2016.

8. Paramartha NLT. Prevalensi dan Karakteristik Carpal Tunnel Syndrome Pada Bulan April 2015 - Oktober 2016 di RSUP Sanglah Denpasar. Denpasar: Skripsi Unversitas Udayana. 2016.

9. Dogan SK, Ay S, Evcik D, Baser O. Adaptation of Turkish version of the questionnaire Quick Disability of the Arm, Shoulder and Hand (Quick DASH) in patients with carpal tunnel syndrome. Clinical Rheumatology. 2010;30(2):185191.

10. Burhan E, Manjas M, Riza A. and Erkadius. Perbandingan Fungsi Extremitas Atas pada Fraktur Metafise Distal Radius Intraartikuler Usia Muda Antara Tindakan Operatif Dan Non Operatif dengan Penilaian Klinis Quickdash Score. Jurnal Kesehatan Andalas. 2014;3(1):32-36.

11. Utoyo G, Chaidir M, Hidajat N, Rasyid H. Korelasi Antara Dash (Disabilities Of The Arm, Shoulder And Hand) Dan Modifikasi Dash Pada Patah Tulang Ujung Distal Radius Di Rumah Sakit Dr. Hasan Sadikin Bandung. Majalah Orthopedi Indonesia. 2009;37(1):14-25.

12. Nugraha MHS, Antari NKAJ, and Saraswati NLPGK. Validity And Reliability Of The Modification Of Northwick Park Neck Pain Questionnaire In Indonesian Version Following Cross-Cultural Adaptation In Mechanical Neck Pain. Majalah Ilmiah Fisioterapi Indonesia. 2019;7(3):1-4.

13. Matondang Z. Validitas Dan Reliabilitas Suatu Instrumen Penelitian. Jurnal Tabularasa PPS Unimed. 2009;6(1):8797. 